\title{
EDITORIAL
}

\section{O Tempo Reencontrado}

Criada visando a divulgação de trabalhos científicos de pesquisadores em início de carreira, a Revista Vernáculo tem, hoje, o desafio de sobreviver a seus criadores. Quando concebida por alunos da Universidade Federal do Paraná no ano 2000, ela funcionava como uma espécie de mecanismo de sublimação para as tensões e indefinições daquele período específico. Com o passar dos anos, porém, as pessoas originalmente envolvidas no projeto acabaram por tocar suas vidas, nas quais a Revista não mais aplacava os novos anseios e preocupações surgidos. Assim, tomar a permanência daqueles alunos como um pré-requisito para a manutenção deste espaço é anunciar o inviável - obrigando a Revista ou a deixar de existir, ou mesmo a mudar com eles. Se, por outro lado, mantêm-se os mesmos dilemas originais, agora enfrentados por outros colegas, há um grande chance de sucesso. Mas fica a pergunta: do que tratam tais dilemas?

Ora, responder esta questão implica no entendimento geral do que é cursar uma graduação. No mais das vezes não se obtém daí uma resposta absoluta, definitiva. Isso se dá porque ser um graduando implica em ter diante de si um vasto número de possibilidades: é o momento da juventude, como aquele vivenciado por Frederico em A Educação Sentimental; tempo das indefinições e incertezas frente às quais tudo parece possível, plausivel. Tempo de descobertas, mas também de escolhas... dos objetos de pesquisas, dos círculo de amizades, etc. Apenas com o tempo percebe-se a transformação das outrora tão numerosas possibilidades em sombras, por vezes assustadoras, do que poderia ter sido e nunca foi.

A Revista Vernáculo auxiliou e, espera-se, auxilie nestas escolhas, enquanto elas são ainda numerosas e confusas. Publicar algo nela, ou mesmo envolver-se com a sua administração, implica em uma tomada de posição. É importante manter mais este canal aberto, tanto por sua maior sintonia com a situação dos alunos, como também por conta dos parcos (e muitas vezes incompreensíveis) incentivos da academia. Se não há como fugir indefinidamente das escolhas, que elas sejam, ao menos, materializadas aqui e tornadas objeto de reflexão. Quem sabe assim a Revista persista, reencontrando seu próprio tempo.

\footnotetext{
${ }^{1}$ Mestrando em História Social/USP; Bolsista FAPESP.
} 